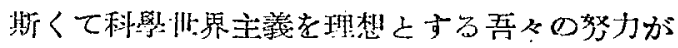

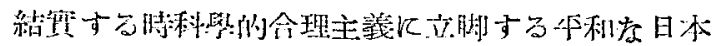

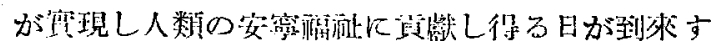
るであらう。

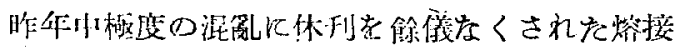

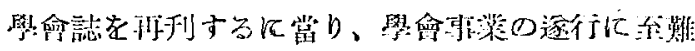

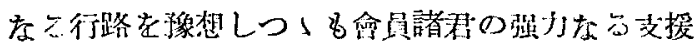

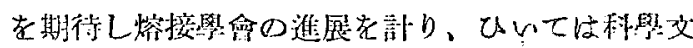

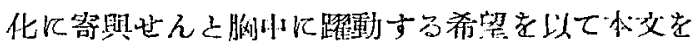
等する次第である。

(昭和2151.19204)

\title{
THE URGENT NECESSITY OF THE PROMOTION OF WELDING
}

\section{BY MINORU OKADA}

\section{The president of The Japan Welding Society}

Before and during the war, the utility of welding technique was scarcely recognized in Japan. Even the responsible experts concerned to production of munitions, they had not the ad. quate appreciation of it.

In spite of the above circumstances, some parties of welding engineers and workers did their best and obtained good risults on qualities and quantities of the product.

Hereafter such their efforts should be more required for the reconstruction works in Japan It is an important problem for urgent solution, that is to say, erection or restoration of factories, harbours, residences, ships, vehicles and the other machines destroyed during the war. And these are examples that depend great deal upon the application of welding.

The more welding experts cooperate strongly, the sooner progress of welding technique woutd be realized. So we must make our every efforts to digest the excellent parts of sciences and atts in America and Europe.

In a word we have to make the most of our experimences of hard work in the war, to encourage the promotion of technique and then we are able to find the glorious hope in the cosmopolitanism set up on sciences and arts which are to contribute to the warfare of mankind in the wotid.

\section{論 文 及 報 告 大要}

\section{融合龽接法（ユニオンォルト法）}

汪是毒木 传太郎

\section{1. 序}

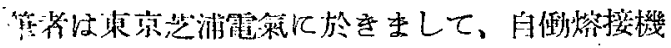

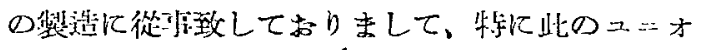

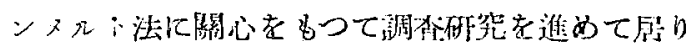
ました關係、御說明中しはげをいと狋じます。
Product Co.で始方主したものでありまして、そ れでニオンといふ後がついてるると思ひます。

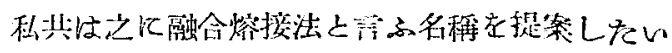

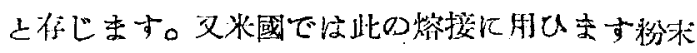

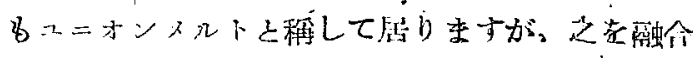

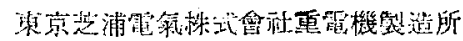




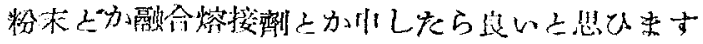

\section{2. 作用の大要}

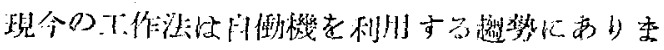

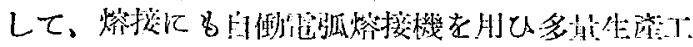

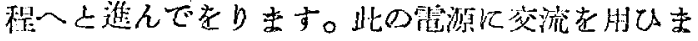

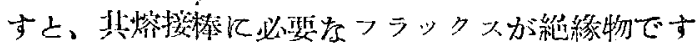

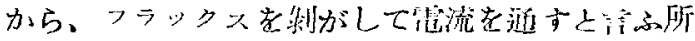
に大分㜀跳があり從來忙主として㨁流が肞しられ

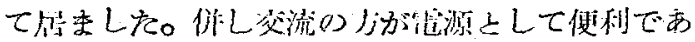

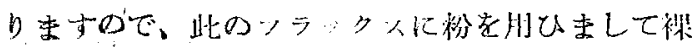

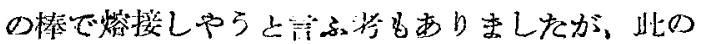

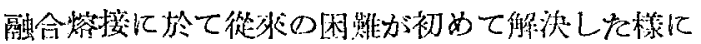
思ひ东す。

扯、融合熔接の原理を御訜明致すのですが、此 の使ひ力接目㷝接亡點聺接があります。

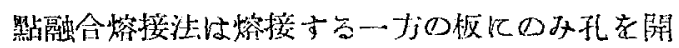
けるタので、其の孔の中に篦極棒之熔揬劑を入れ

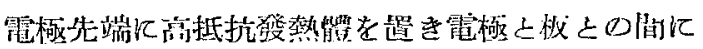

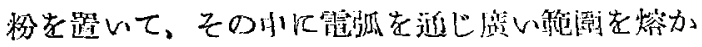
して接命するのであります。

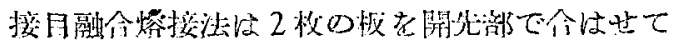

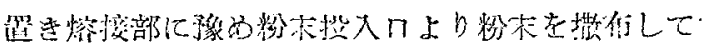

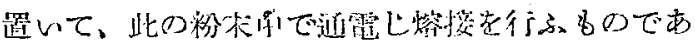
bま

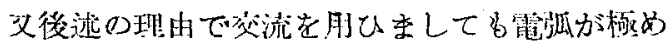

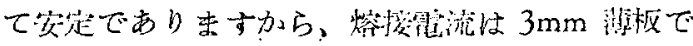
b $600 \mathrm{~A}$, 又 $60 \mathrm{~mm}$ 鐵板では 3000A 孝䢎し 1 [i门]

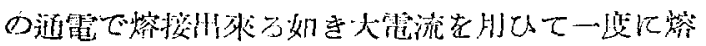

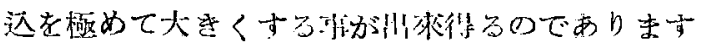

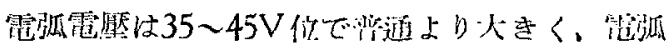

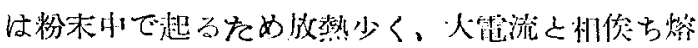

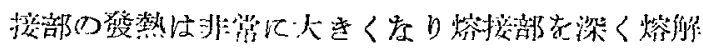

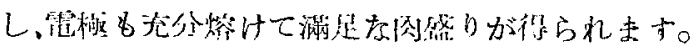

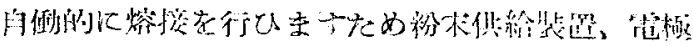

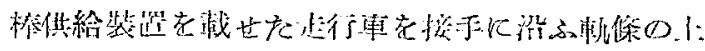

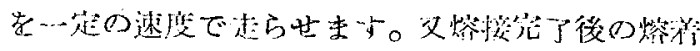

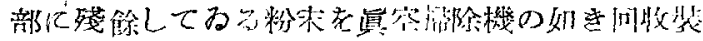

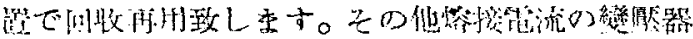

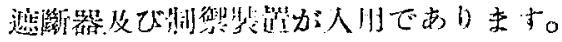

\section{3. 電極棒の供給装置}

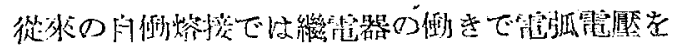

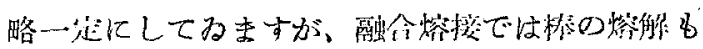

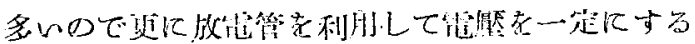

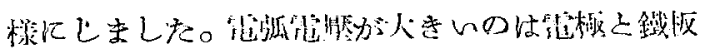

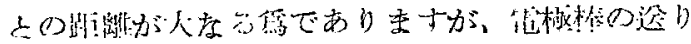

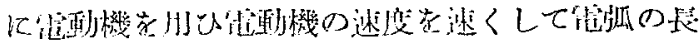

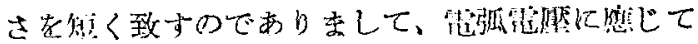

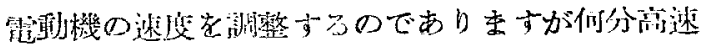

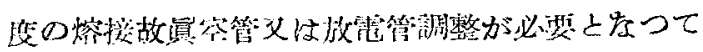
來をのであります。

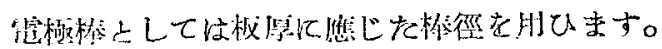

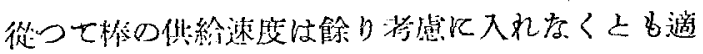
莞なものがあります。

\section{4. 熔接裝置の用品}

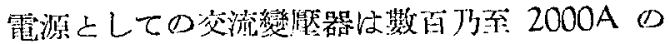

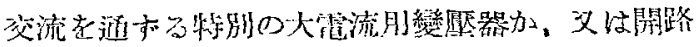

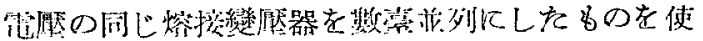

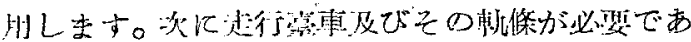

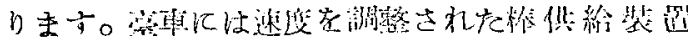

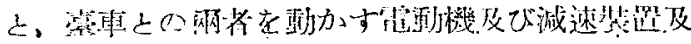

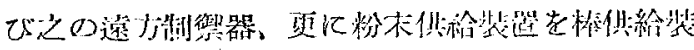

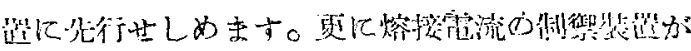
必琵であり专す。

\section{5. 熔接電流と熔接速度及び開先}

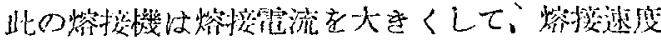

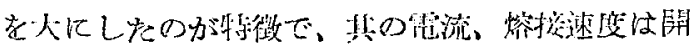

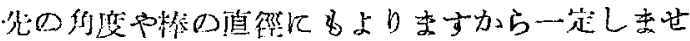

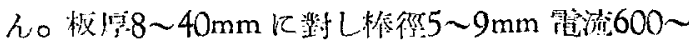

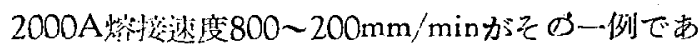

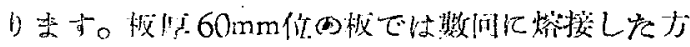

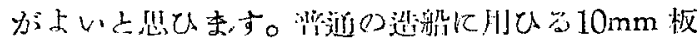
では 1000 1500A $5000-700 \mathrm{~mm} / \mathrm{min}$

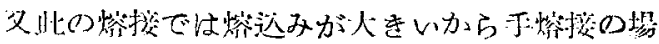




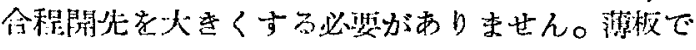

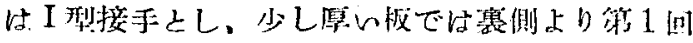

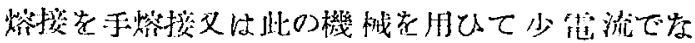
し、然各後表面上り峑接を行ひます。30 $\mathrm{mm}$ 以上

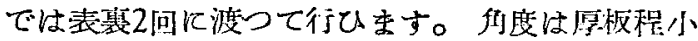
さいオが良いと思します。

\section{6. 熔接劑之熔接棒}

此の摈接法で一罪䦕題になるのは济接劑粉末で あります。之に對しまして現在2種類の配合が提稪 せられて利㞦されて居り字すその第1はCa，Mg

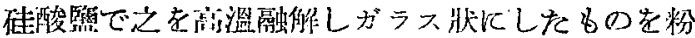
末にしたbのであります。籍 2 は $\mathrm{Al}_{2} \mathrm{O}_{3}$ 亡 $\mathrm{SiO}_{2}$ した結晶涉のものであります。共に 1300～1400 程度の揢稚溫度であります。

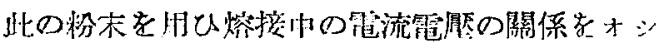

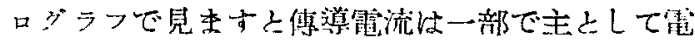

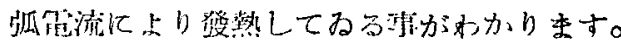

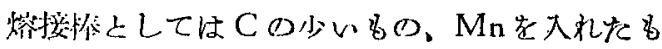

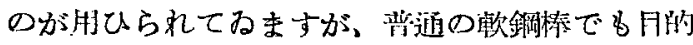
が果せをず。

\section{7. 結言}

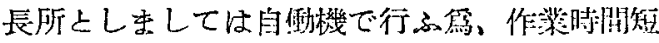
緛、材料節約及び良效索る煏接結果を得られる等

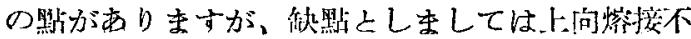

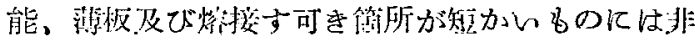

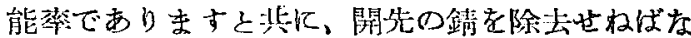
らない事等がありますが、之を使用して行くりれ それ等の缺點も改良されるものよ思ひます。

\section{新己き圓板電弧熔接法に就いて}

\section{王虽美馬 源 次 郎}

\section{1. 序}

$\overline{\overline{\bar{z}}}$

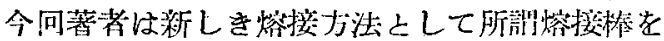

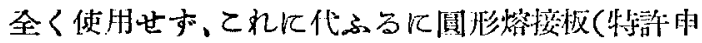
告番號7117號) を为ひて摈接を行ふ可く将へた。 てれが祀ち新しき圆板電弧熔接法である。ての塔

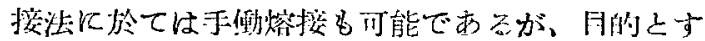

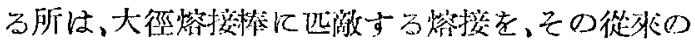

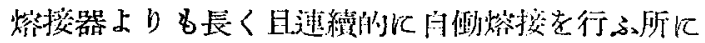

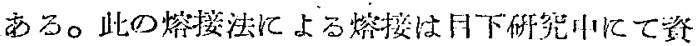

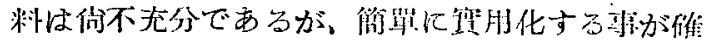

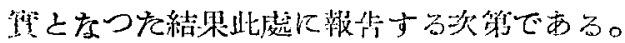

\section{2. 熔接機の構造及び愹接方法}

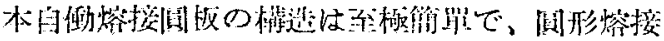

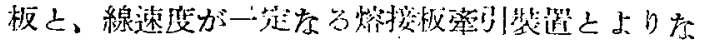

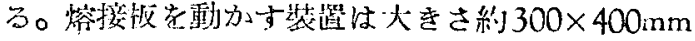

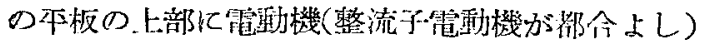

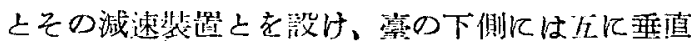

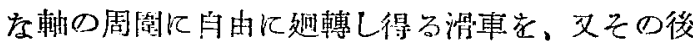

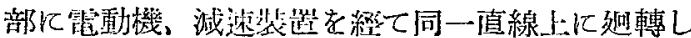

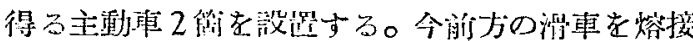

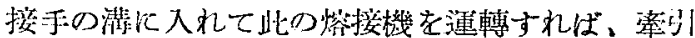
車は综接線上を佂䈍の定速度で媈行し、えに引か

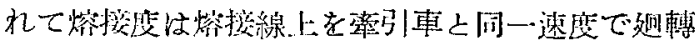
湔進す字。

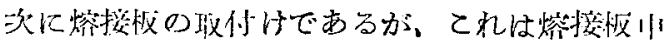

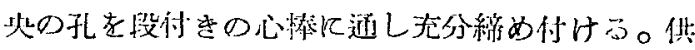

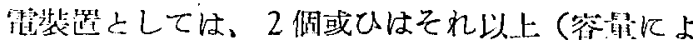

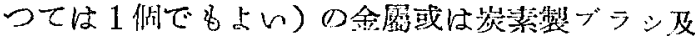

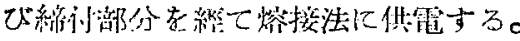

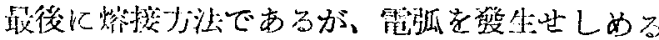

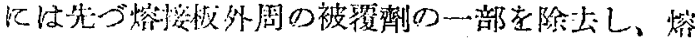

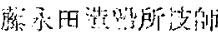

